\title{
The growth of Staphylococcus aureus and Escherichia coli in low-direct current electric fields
}

\author{
Dunya Zituni ${ }^{1}$, Heidi Schütt-Gerowitt ${ }^{2}$, Marion Kopp ${ }^{1}$, Martin Krönke ${ }^{2}$, Klaus Addicks ${ }^{3}$, Christian Hoffmann ${ }^{3}$, \\ Martin Hellmich ${ }^{4}$, Franz Faber ${ }^{5}$ and Wilhelm Niedermeier ${ }^{1}$
}

Electrical potentials up to $800 \mathrm{mV}$ can be observed between different metallic dental restorations. These potentials produce fields in the mouth that may interfere with microbial communities. The present study focuses on the impact of different electric field strengths (EFS) on the growth of Staphylococcus aureus (ATCC 25923) and Escherichia coli (ATCC 25922) in vitro. Cultures of S. aureus and E. coli in fluid and gel medium were exposed to different EFS. Effects were determined by calculation of viable counts and measurement of inhibition zones. In gel medium, anodic inhibition zones for $S$. aureus were larger than those for $E$. coli at all field strength levels. In fluid medium, the maximum decrease in the viable count of $S$. aureus cells was at $10 \mathrm{~V} \cdot \mathrm{m}^{-1}$. Field-treated $S$. aureus cells presented ruptured cell walls and disintegrated cytoplasm. Conclusively, $S$. aureus is more sensitive to increasing electric field strength than $E$. coli.

International Journal of Oral Science (2013) 6, 7-14; doi:10.1038/ijos.2013.64; published 6 September 2013

Keywords: direct current; Escherichia coli; electrogalvanism; gold electrode; Staphylococcus aureus

\section{INTRODUCTION}

Different metallic restorations are used in dentistry to restore decayed, fractured and missing teeth. When different alloys are placed in the oral cavity, a galvanic current is induced at the time of their contact with saliva which acts as an electrolyte. ${ }^{1-3}$ This phenomenon is called oral galvanism. ${ }^{4-7}$ Dental alloys develop an anodic and cathodic pole depending on the position of metals in electrochemical series and individual variations of saliva. ${ }^{8}$ A potential as high as $950 \mathrm{mV}$ has been measured in the oral cavity between an aluminium splint and a gold crown. ${ }^{9}$ Such potential can decrease the proliferation rate of oral mucosa cancer cells lines ${ }^{10}$ and also cause local or systemic adverse effects on biological structures like pain and discomfort, metallic or salty taste, burning mouth syndrome, erythema, xerostomia, glossitis and oral mucosal lesions ${ }^{9,11-14}$. It may also cause general medical symptoms and diseases due to the absorption of ionized toxic metals. ${ }^{9}$ In addition, such potentials may induce changes in oral homeostasis through their direct or indirect interference with oral ecosystems. Since changes in environmental factors can stimulate the development of adaptive responses in individual microorganisms and introduce more pathogenic microorganisms into the microbial community, ${ }^{15}$ the effect of electric fields on microbial communities was the area of interest.

Staphylococcus aureus are roughly spherical Gram-positive cocci that can be frequently isolated from the oral cavity of particular patient groups such as children and elderly. ${ }^{16-17}$ Smith et al. ${ }^{18}$ isolated methicillin-sensitive $S$. aureus (MSSA) and methicillin-resistant $S$. aureus from the oral cavity by an oral rinse and a tongue swab respectively. They reported that $S$. aureus might be a more frequent isolate from the oral cavity than hitherto suspected. In addition, Ohara-Nemoto et al. ${ }^{19}$ demonstrated that the most frequently isolated species in saliva was $S$. aureus followed by S. epidermidis and confirmed the highly significant occurrence of oral staphylococci in systemically and periodontally healthy adult. On the other hand, Escherichia coli are Gram-negative rods and are an extensively studied model organism; probably the best-understood bacterium at all. ${ }^{20}$

The present study was conducted to investigate the effects of lowdirect current (LDC) electric fields and their electrochemical products on S. aureus and E. coli in vitro within fluid and gel media to explain the similar or different effects of galvanic currents on normal growth of oral bacteria in different salivary constituents that influence the equlibrium state of oral cavity and thus producing diseases.

\section{MATERIALS AND METHODS}

Voltage generated by electrodes in tryptic soy broth, $\mathrm{NaCl}$ and distilled water

To test in absence of direct current (DC) supply, if tryptic soy broth (TSB) with immersed gold electrodes play a role in producing potentials, two holes were drilled into the cover of 9.4-cm Petri dish, each is

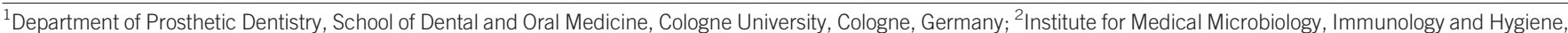

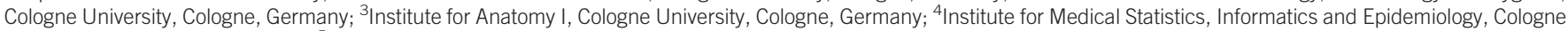
University, Cologne, Germany and ${ }^{5}$ Department of Pre-Clinical Dentistry, School of Dental and Oral Medicine, Cologne University, Cologne, Germany

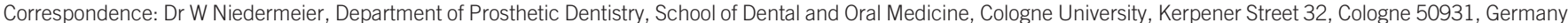

E-mail: wilhelm.niedermeier@uk-koeln.de

Dr D Zituni, Department of Prosthetic Dentistry, School of Dental and Oral Medicine, Cologne University, Glas Street 79, Cologne 50823, Germany

E-mail: dunya.zituni@yahoo.de

Accepted 14 June 2013 
$0.5 \mathrm{~cm}$ apart from the centre (area of field homogeneity) and two measuring gold electrodes were passed through the drilled holes (Figure 1). Three Petri dishes, each with four gold electrodes (Solaris Goldbad, 99.9\% pure gold; DeguDent, Hanau-Wolfgang, Germany) were used. A-24 mL of each; TSB (positive control 1), $0.9 \% \mathrm{NaCl}$ (positive control 2) and distilled water (Aqua bidest DAB; Servoprax, Am Marienbusch, Wesel, Germany) (24 mL of each) as a negative control were poured in the dishes that were incubated at $37{ }^{\circ} \mathrm{C}$ for $24 \mathrm{~h}$. The two measuring electrodes were connected to a sensitive voltmeter (2 000 Multimeter, ID-NR: 20009867; Keithley, Cleveland, OH, USA) and the potential difference in every dish was measured every hour for $8 \mathrm{~h}$ and at $24 \mathrm{~h}$.

\section{Voltage generated by electrodes in TSB containing bacteria}

To measure the voltage generated by gold electrodes that were not connected to a DC supply, $24 \mathrm{~mL}$ of TSB and $1 \mathrm{~mL}$ of bacterial suspension $\left(10^{-1}\right.$ dilution in $0.9 \%$ sterile saline of McFarland 0.5$)$ were poured in Petri dish. The dish was then incubated with four gold electrodes at $37^{\circ} \mathrm{C}$ for $24 \mathrm{~h}$ and the potential difference between two measuring electrodes was measured every hour for $8 \mathrm{~h}$ and at $24 \mathrm{~h}$.

\section{Survival rates of $S$. aureus and E. coli at different electric field strengths}

Strains of S. aureus (ATCC 25923) and E. coli (ATCC 25922) were provided as cultures grown overnight on blood agar plates. Three Petri dishes were used, $24 \mathrm{~mL}$ of TSB and $1 \mathrm{~mL}$ of the bacterial suspension $\left(10^{-1}\right.$ dilution in $0.9 \%$ sterile saline of McFarland 0.5 ) were poured into every dish and a figure eight movement was done to evenly distribute bacteria. The three dishes were for: field-stimulated bacteria (FSB), electrode-stimulated bacteria (electrodes not connected to an external DC power supply (ESB)) and negative control bacteria (neither current nor electrodes (NCB)). Gold electrodes were immersed perpendicularly in the periphery of the first two dishes, four electrodes in each (Figure 1). The distance between each two opposing electrodes was $9.3 \mathrm{~cm}$. The first dish electrodes were connected to a DC supply

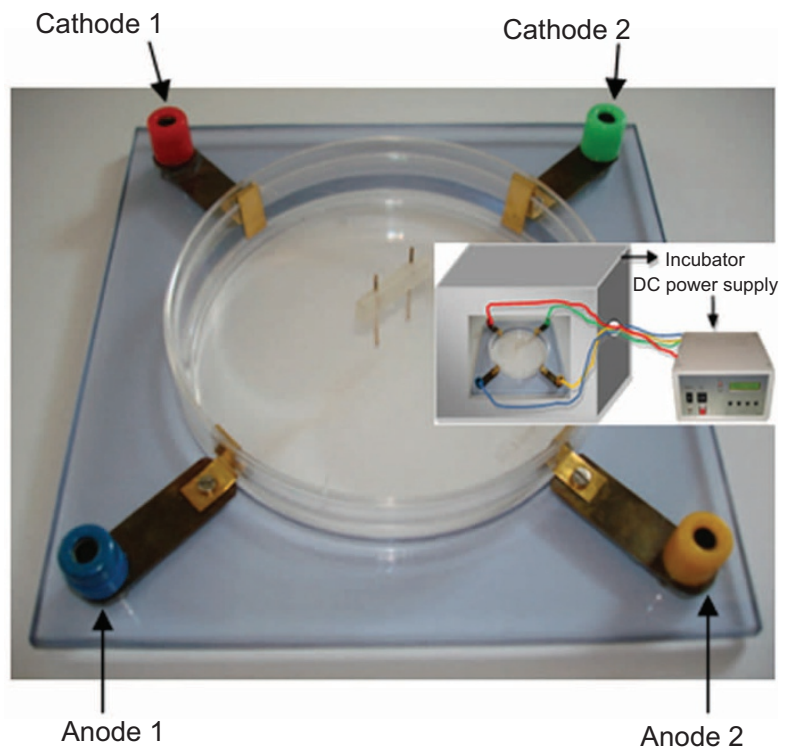

Figure 1 Four gold electrodes placed at equal distances of $90^{\circ}$ each. The distance between each two opposing electrodes $=9.3 \mathrm{~cm}$ with two measuring gold electrodes in the center of Petri dish. (two anodes and two cathodes) that generates a DC voltage between 0 and $2.5 \mathrm{~V}$.

During the experiments, S. aureus and E. coli were exposed separately to electric field strengths $(\mathrm{EFS})$ of $2-10 \mathrm{~V} \cdot \mathrm{m}^{-1}$. The three dishes were incubated at $37^{\circ} \mathrm{C}$ for $24 \mathrm{~h}$. $\mathrm{pH}$ and temperature were measured using $\mathrm{pH}$ test strips and a thermometer (THM 912; Oregon Scientific, Rue du Bosquet, Louvain-La-Neuve, Belgium). Aliquot $0.5 \mathrm{~mL}$ samples were taken at the first anode from the first dish, at the first electrode from the second dish and from the negative control dish every hour during the initial $8 \mathrm{~h}$ and at $24 \mathrm{~h}$. For each sample, serial dilutions up to $10^{-6}$ dilutions were performed using sterile saline (0.9\%). Each diluted sample was pipetted onto the surface of blood agar and incubated at $37{ }^{\circ} \mathrm{C}$ for $24 \mathrm{~h}$. The survival rate in terms of bacterial count was expressed as $\lg \left(\mathrm{CFU} \cdot \mathrm{mL}^{-1}\right)$.

\section{Electric currents produced in TSB containing bacteria after DC voltage induction}

In EFS experiments of $2-10 \mathrm{~V} \cdot \mathrm{m}^{-1}$, the intensity of arising electric currents in TSB containing bacteria was measured using DasyLab software programme (DASYLab; DATALOG, Mönchengladbach, Germany).

\section{Inhibition zones for $S$. aureus and $E$. coli at different electric field} strengths

One milliliter of bacterial suspension $\left(10^{-5}\right.$ dilutions in $0.9 \%$ sterile saline of McFarland 0.5) was cultivated on two Mueller-Hinton agar (MHA) plates, $0.5 \mathrm{~mL}$ in every plate. The two MHA plates were used for FSB and ESB. After the absorption of the bacterial suspension, the two plates were incubated at $37{ }^{\circ} \mathrm{C}$ for $24 \mathrm{~h}$. EFS of $5-27 \mathrm{~V} \cdot \mathrm{m}^{-1}$ were applied on FSB plate, each for $24 \mathrm{~h}$. The radius of each inhibition zone was measured.

\section{Transmission electron microscopy}

Microbial growth and cell survival dynamics under electric field treatment of $\left(4,6\right.$ and $\left.10 \mathrm{~V} \cdot \mathrm{m}^{-1}\right)$, electrode treatment and the relative negative controls were observed using transmission electron microscopy (TEM). The collected cells were harvested by centrifugation for $10 \mathrm{~min}$ at $6440 \mathrm{~g}$ in a Hettich Rotanta/S centrifuge and fixed using glutaraldehyde for $24 \mathrm{~h}$. Then, the cells were rinsed, postfixed in osmium tetroxide for $3 \mathrm{~h}$, dehydrated in ethanol in ascending grades and embedded in Epon Araldite. Following this, the ultrathin sections were examined using TEM (Zeiss TEM 902; Carl Zeiss Lithos, Oberkochen, Germany).

\section{Statistical analysis}

Data was recorded and analyzed in the data module of the Statistical Package for Social Science (IBM SPSS Statistics 19) for Windows (IBM, Somers, NY, USA). The results are presented as means \pm s.d. Significant differences in survival rate were assessed by repeated measures analysis of variance (ANOVA) with Bonferroni (step-down) Holm correction. Inhibition zone experiments were evaluated statistically using univariant ANOVA with Bonferroni (step-down) Holm correction. A value of $P \leqslant 0.05$ was used to determine statistical significance between different means of different cells (FSB, ESB and NCB) and between the inhibition zones for both strains; $P \leqslant 0.05$ was considered significant.

\section{RESULTS}

Voltage generated by electrodes in TSB, $\mathrm{NaCl}$ and distilled water The voltage generated by the electrodes in TSB without any connection to a DC supply was $260.55 \mathrm{mV}\left(2.8 \mathrm{~V} \cdot \mathrm{m}^{-1}\right) \pm 47.59 \mathrm{mV}$, in $0.9 \%$ 
Table 1 Voltage generated by gold electrodes in different media without DC voltage induction

\begin{tabular}{lccc}
\hline & \multicolumn{3}{c}{ Voltage generated by electrodes in different media/mV } \\
\cline { 2 - 4 } Time/h & $\begin{array}{c}\text { TSB } \\
\text { (positive control 1) }\end{array}$ & $\begin{array}{c}\text { NaCl } \\
\text { (positive control 2) }\end{array}$ & $\begin{array}{c}\text { Distilled water } \\
\text { (negative control) }\end{array}$ \\
\hline 0 & 191 & 22.5 & 15 \\
1 & 209 & 33 & 11.5 \\
2 & 268 & 50 & 6.5 \\
3 & 299 & 67.5 & 3 \\
4 & 200 & 79 & 5 \\
5 & 346 & 87.5 & 2.5 \\
6 & 336 & 71 & 2.5 \\
7 & 248 & 63 & 2.5 \\
8 & 296 & 58.5 & 3 \\
24 & 269 & 50 & 3 \\
Mean \pm s.d. & $266 \pm 51.75$ & $58.2 \pm 19$ & $5.45 \pm 4.16$ \\
Corr. value & $260.55 \pm 47.59$ & $52.75 \pm 14.84$ & \\
\hline
\end{tabular}

TSB, tryptic soy broth; Corr. value, corrected value $=$ mean of positive control $(1$ or 2)-mean of negative control; DC, direct current; s.d., standard deviation.

$\mathrm{NaCl}$ was $52.75 \mathrm{mV}\left(0.6 \mathrm{~V} \cdot \mathrm{m}^{-1}\right) \pm 14.84 \mathrm{mV}$ and in distilled water was $5.45 \mathrm{mV}\left(0.06 \mathrm{~V} \cdot \mathrm{m}^{-1}\right) \pm 4.16 \mathrm{mV}($ Table $1, n=2)$.

Voltage generated by electrodes in TSB containing bacteria The voltages generated from electrodes-stimulated $S$. aureus and E. coli were $274.69 \mathrm{mV}\left(2.9 \mathrm{~V} \cdot \mathrm{m}^{-1}\right) \pm 68.33 \mathrm{mV}$ and $226.53 \mathrm{mV}$ $\left(2.4 \mathrm{~V} \cdot \mathrm{m}^{-1}\right) \pm 33.38 \mathrm{mV}$, respectively. Thus, the electrodes in TSB containing bacteria in absence of current produce EFS of $\leqslant 3 \mathrm{~V} \cdot \mathrm{m}^{-1}(n=5)$.

\section{Survival rates of $S$. aureus and $E$. coli at different electric field} strengths

Electrical field treatment $\left(4-10 \mathrm{~V} \cdot \mathrm{m}^{-1}\right)$ led to a decrease of the survival rate of $S$. aureus from $(7.11 \pm 0.22) \mathrm{lg}\left(\mathrm{CFU} \cdot \mathrm{mL}^{-1}\right)$ to $(6.01 \pm 0.2)$ $\lg \left(\mathrm{CFU} \cdot \mathrm{mL}^{-1}\right)$. For ESB, the survival rate decreases from $(6.88 \pm 0.25)$ $\lg \left(\mathrm{CFU} \cdot \mathrm{mL}^{-1}\right)$ to $(6.10 \pm 0.4) \lg \left(\mathrm{CFU} \cdot \mathrm{mL}^{-1}\right)$ when compared to the initial bacterial load from $(7.56 \pm 0.26) \mathrm{lg}\left(\mathrm{CFU} \cdot \mathrm{mL}^{-1}\right)$ to $(7.00 \pm 0.39)$ $\lg \left(\mathrm{CFU} \cdot \mathrm{mL}^{-1}\right)$. In contrast for E. coli, EFS of $2-10 \mathrm{~V} \cdot \mathrm{m}^{-1}$ and electrodes alone showed no change in the survival rate (Figure $2, n=2$ ). In all experiments, there was no significant change in $\mathrm{pH}$ and temperature; the range of $\mathrm{pH}$ (from 7 to 6) and temperature (from $36.9^{\circ} \mathrm{C}$ to $37.2{ }^{\circ} \mathrm{C}$ ) measured in all treated and control dishes were similar.

Electric currents produced in TSB containing bacteria after DC voltage induction

In TSB containing $S$. aureus, the intensity of current increased gradually from $(106.17 \pm 0.69) \mu \mathrm{A}$ to $(567.56 \pm 86.71) \mu \mathrm{A}$ with the increase in

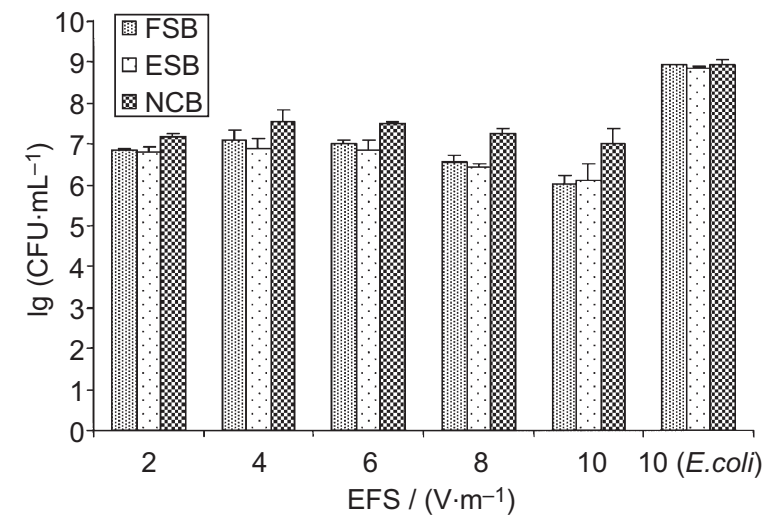

Figure 2 Survival rates of $S$. aureus and $E$. coli after the exposure to different EFS in $24 \mathrm{~h}$. The first 2, 4, 6, 8 and $10 \mathrm{~V} \cdot \mathrm{m}^{-1}$ for $S$. aureus and 10 (E. coli) is a representative experiment to $E$. colitests. CFU, colony-forming unit; EFS, electric field strength $\left(\mathrm{V} \cdot \mathrm{m}^{-1}\right)$; $\mathrm{ESB}$, electrode-stimulated bacteria; FSB, field-stimulated bacteria; NCB, negative control bacteria.

Table 2 The intensity of current and the resistance of bacteria in TSB at different electric field strengths

\begin{tabular}{|c|c|c|c|c|}
\hline Bacteria & $\mathrm{EFS} /\left(\mathrm{V} \cdot \mathrm{m}^{-1}\right)$ & $\mathrm{EP} / \mathrm{mV}$ & Intensity of current $/ \mu \mathrm{A}$ & Resistance/k $\Omega$ \\
\hline \multirow[t]{5}{*}{ S. aureus } & 2 & 200 & $106.17 \pm 0.69$ & 1.88 \\
\hline & 4 & 400 & $204.05 \pm 3.67$ & 1.96 \\
\hline & 6 & 600 & $289.52 \pm 37.09$ & 2.07 \\
\hline & 8 & 800 & $383.29 \pm 45.71$ & 2.09 \\
\hline & 10 & 1000 & $567.56 \pm 86.71$ & 1.76 \\
\hline E. coli & 10 & 1000 & $289.13 \pm 215.02$ & 3.46 \\
\hline
\end{tabular}

EFS, electric field strength; EP, electric potential; TSB, tryptic soy broth.

field strength from 2 to $10 \mathrm{~V} \cdot \mathrm{m}^{-1}$ (Table $2, n=5$ ). On the other hand, the intensity of current in TSB containing E. coli was $(289.13 \pm 215.02) \mu \mathrm{A}$ at $10 \mathrm{~V} \cdot \mathrm{m}^{-1}$.

Inhibition zones for $S$. aureus and $E$. coli at different electric field strengths

Zones of inhibition of varying sizes were observed at the positive electrode (anode) at all field strengths for both bacterial strains (Table 3). Electrical field treatment $\left(5-27 \mathrm{~V} \cdot \mathrm{m}^{-1}\right)$ of S. aureus and E. coli increases the inhibition zone from $(4.00 \pm 3.83)$ to $(13.75 \pm 1.50) \mathrm{mm}$ and from $(1.63 \pm 0.74)$ to $(12.25 \pm 1.83) \mathrm{mm}$, respectively. No zones of inhibition around the cathode or around sham electrodes (no current) were observed. The radius of zones for $S$. aureus was more than for $E$. coli at all field strength levels $(n=5)$.

Table 3 Inhibition zones produced around the anode at different EFS and $\boldsymbol{P}$-value using univariate ANOVA with Bonferroni (step-down) Holm correction

\begin{tabular}{|c|c|c|c|c|c|}
\hline \multirow[b]{2}{*}{$\mathrm{EFS} /\left(\mathrm{V} \cdot \mathrm{m}^{-1}\right)$} & \multirow[b]{2}{*}{$\mathrm{EP} / \mathrm{mV}$} & \multicolumn{2}{|c|}{ Inhibition zones/mm } & \multicolumn{2}{|c|}{ IZs vs. IZe } \\
\hline & & IZs & IZe & ANOVA & ANOVA+Bonferroni-H \\
\hline 5 & 500 & $4.00 \pm 3.83$ & $1.63 \pm 0.74$ & 0.019 9* & $0.0398 *$ \\
\hline 10 & 1000 & $7.00 \pm 2.16$ & $2.88 \pm 0.84$ & $0.00012 *$ & $0.00048 *$ \\
\hline 16 & 1500 & $7.75 \pm 1.71$ & $4.25 \pm 1.17$ & $0.00086 *$ & 0.002 58* \\
\hline 22 & 2000 & $11.25 \pm 1.89$ & $6.50 \pm 0.76$ & $0.00001 *$ & $0.00005^{*}$ \\
\hline 27 & 2500 & $13.75 \pm 1.50$ & $12.25 \pm 1.83$ & 0.13503 & 0.13503 \\
\hline
\end{tabular}

ANOVA, analysis of variance; EFS, electric field strength; EP, electric potential; IZe, inhibition zones for E. coli; IZs, inhibition zones for $S$.aureus.

*Significant $(P \leqslant 0.05)$. 


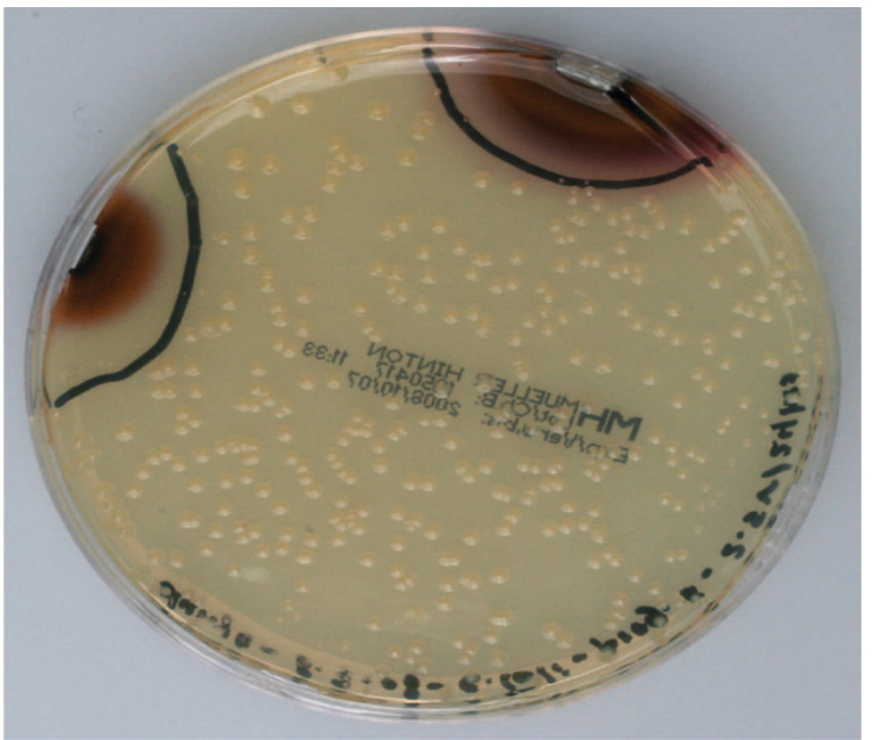

Figure 3 Discoloration of MHA medium observed at anodes when bacteria ( $E$. coli) were exposed to $27 \mathrm{~V} \cdot \mathrm{m}^{-1}$. MHA, Mueller-Hinton agar.

Discoloration of the medium was found at anodes in the experiments with 16,22 and $27 \mathrm{~V} \cdot \mathrm{m}^{-1}$ (Figure 3 ).

\section{TEM}

The LDC electric field treatment applied to $S$. aureus cultures caused alterations in the morphology of cells, rupturing of membrane and loss of cell organization when compared with the control (Figures 4 and 5). Ultrastructurally, the electric field treated cells presented thinner discontinuous or ruptured cell walls with leakage of cytoplasmic material.
The cytoplasmic material leaking out of $S$. aureus cells is seen as debris between the cells as shown in Figure $4 \mathrm{a}$ and $4 \mathrm{~b}$. Blebbing with disintegration of cell material, and shrinkage of the cell were also evident (Figure 5a). Furthermore, the rupturing of the membrane system with loss of cell organization was either evident in electrode treated $S$. aureus cells (Figures 4 and $5 c$ and $5 \mathrm{~d}$ ). The insoluble gold compounds were seen directly in the cell membrane (Figure 6a), inside the cells as small black granules (Figure $6 \mathrm{~b}$ and $6 \mathrm{c}$ ), and indirectly as electron dense vacuoles or bodies (Figure $6 \mathrm{~b}$ ). The yellow-orange precipitate (gold crystalline deposits) in Petri dish after evaporation of TSB supports the present findings (Figure $7 \mathrm{a}$ and $7 \mathrm{~b}$ ). On the other hand, untreated control cells presented as compact dense cells with thick cell walls, distinct organells and normal cell division (Figures 4 and $5 e$ and $5 f$ ).

The electric field treated E. coli showed little changes in cell morphology when compared to control like discontinuous cell membrane with some degrees of disintegration in cytoplasmic materials, which exhibited as vacuoles formation and non homogenous cytoplasm (Figure 8a and 8b). Moreover, the electrode treated cells showed more morphological changes characterized by granulated cytoplasm with some signs of cytoplasmic retraction and extensive vacuoles formation (Figure $8 \mathrm{c}$ and $8 \mathrm{~d}$ ) in contrast to the smooth and continuous double membrane structure of the untreated $E$. coli cells (Figure $8 \mathrm{e}$ and $8 \mathrm{f}$ ).

\section{Statistical analysis}

EFS of $4-10 \mathrm{~V} \cdot \mathrm{m}^{-1}$ led to significant reduction in the growth of $S$. aureus $(P \leqslant 0.05)$ with high reduction at $8-10 \mathrm{~V} \cdot \mathrm{m}^{-1}$, and nonsignificant reduction in the growth of $E$. coli $(P=0.905)$. Moreover, electrodes alone in absence of currents provided (in four out of five cases) significant reduction in $S$. aureus growth $(P \leqslant 0.001)$ and nonsignificant reduction in $E$. coli growth $(P=0.348)$. The difference between FSB and ESB was non-significant $(P \geqslant 0.292)$ for both strains
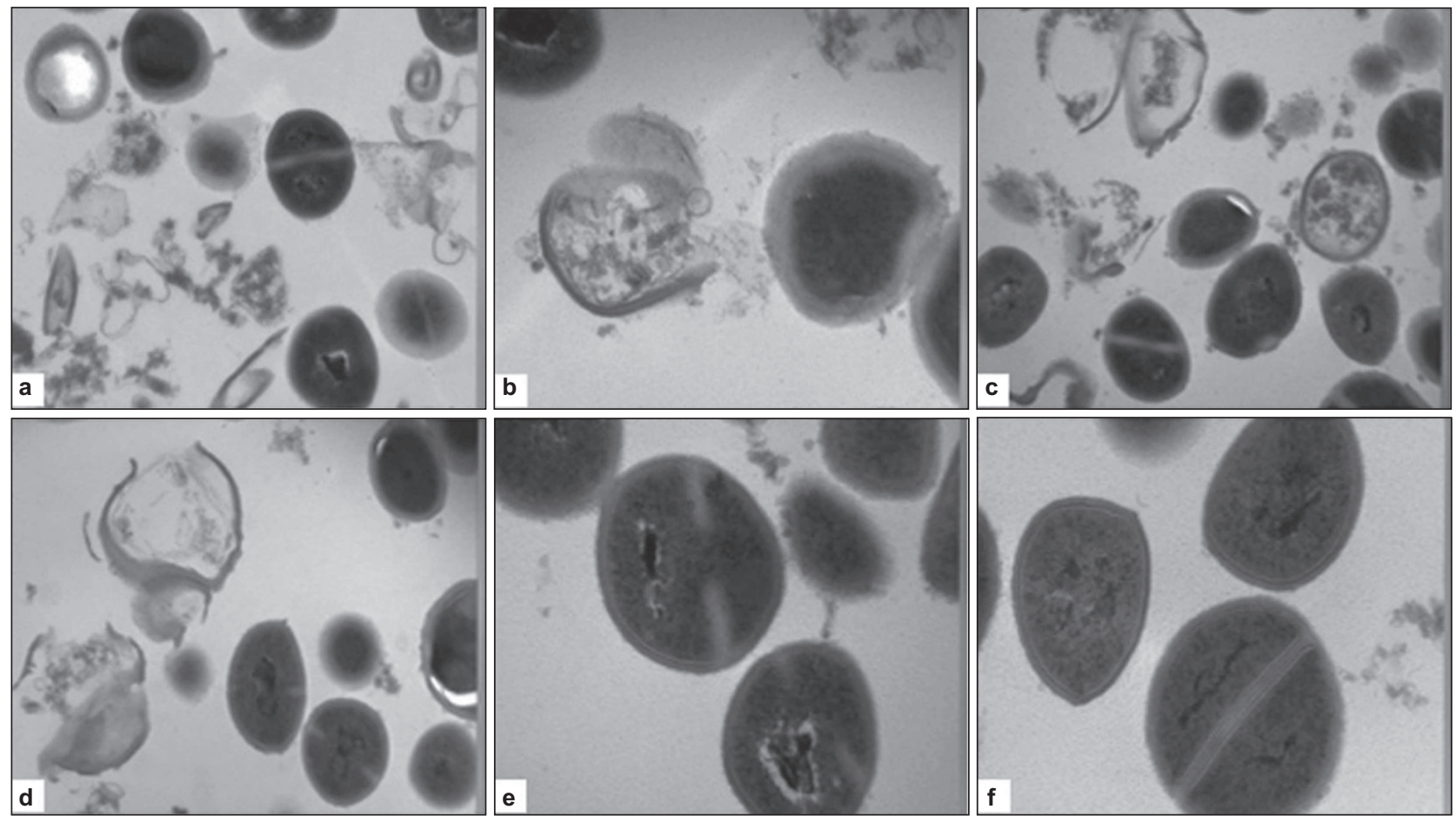

Figure $4 \mathbf{S}$. aureus cells treated with $\mathbf{4} \mathbf{V} \cdot \mathbf{m}^{-\mathbf{1}}$. (a and $\left.\mathbf{b}\right)$ Electric field-treated cells; (c and $\left.\mathbf{d}\right)$ electrode-treated cells; $(\mathbf{e}$ and $\mathbf{f})$ untreated cells. (a, $\mathbf{c}$ and $\left.\mathbf{d}\right) \times 30000$; (b, e and f) $\times 50000$. 

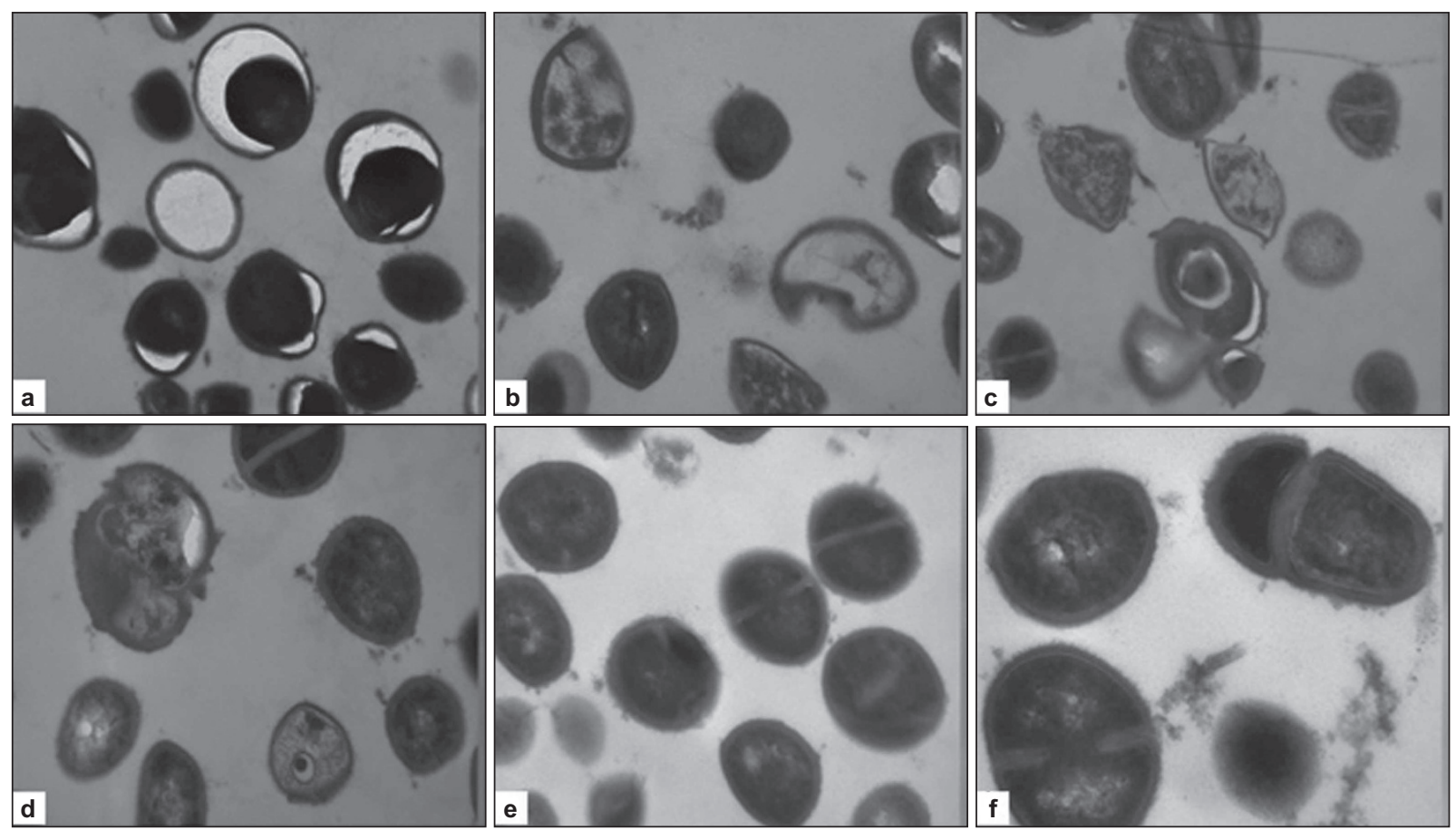

Figure 5 S. aureus cells treated with $6 \mathbf{V} \cdot \mathbf{m}^{-1}$. (a and $\left.\mathbf{b}\right)$ Electric field-treated cells; (c and $\left.\mathbf{d}\right)$ electrode-treated cells; (e and f) untreated cells. (a and $\left.\mathbf{c}\right) \times 20000 ;(\mathbf{b}$, $\mathbf{d}$ and e) $\times 30000$; (f) $\times 50000$.
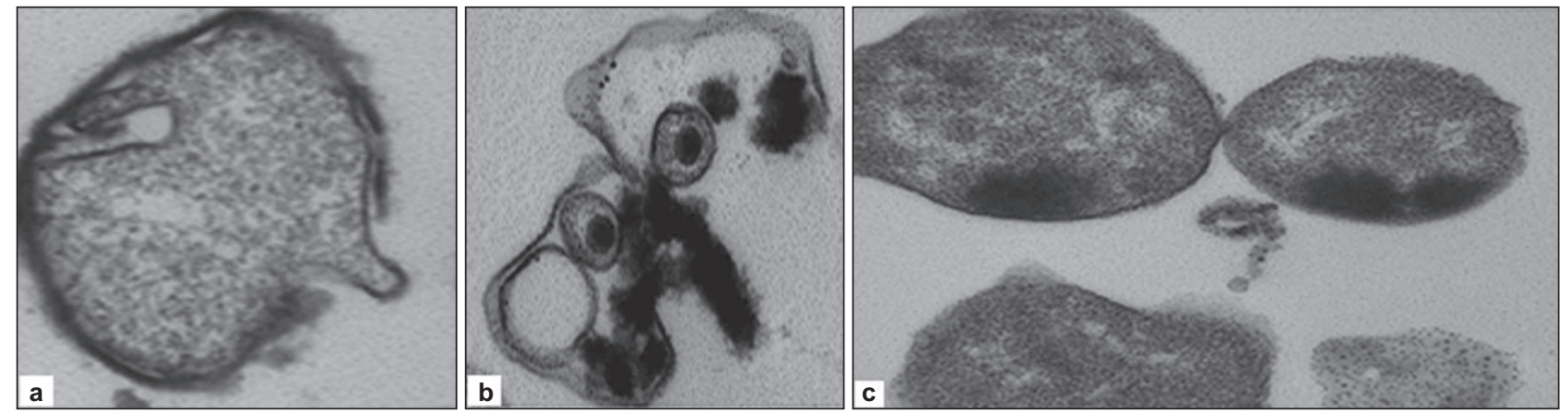

Figure 6 Electrode treated $\boldsymbol{S}$. aureus cells. (a) Gold compounds precipitate in the cell membrane; (b) two electron dense bodies as well-defined opaque vacuoles; (c) gold granules as small black particles inside the cells. $(\mathbf{a}-\mathbf{c}) \times 85000$.
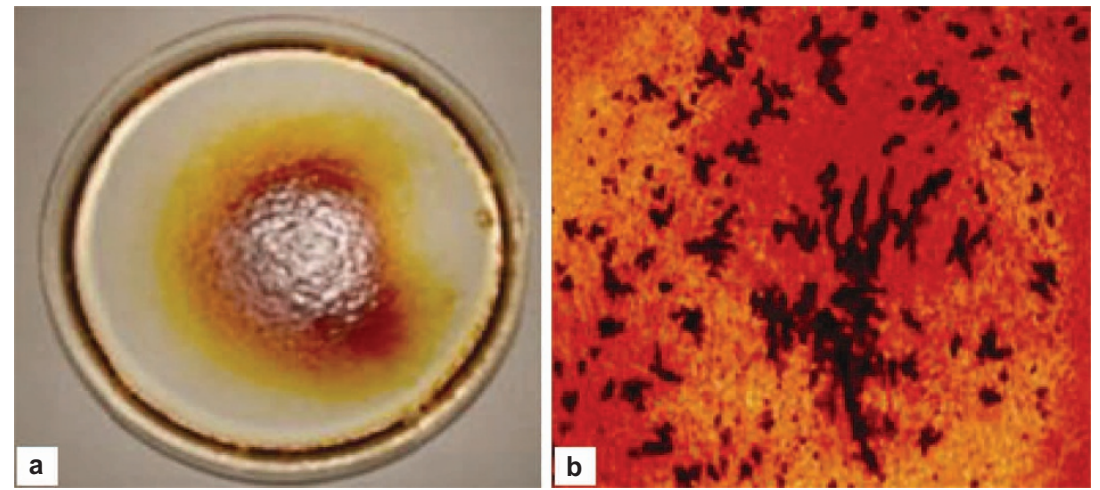

Figure 7 The precipitation of gold after evaporation of bacterial media (TSB) of electrode-treated S. aureus cells. (a) Macroscopic gold precipitate; (b) microscopic gold precipitate $(\times 100)$. TSB, tryptic soy broth. 

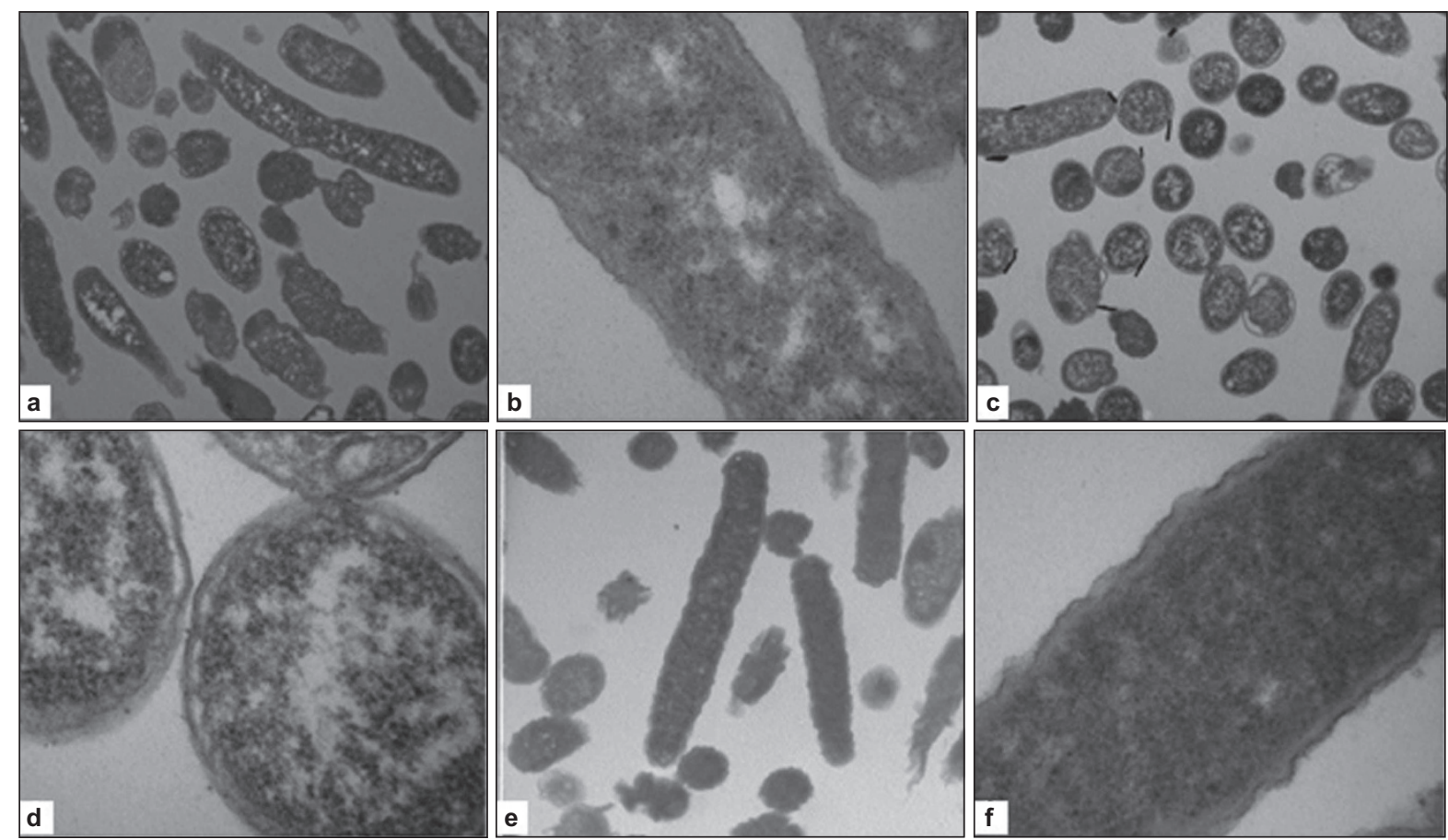

Figure 8 E. colicells treated with $10 \mathbf{~ V} \cdot \mathbf{m}^{-1}$. (a and b) Electric field-treated cells; (c and d) electrode treated cells; (e and f) untreated cells. (a, c and e) $\times 12000(\mathbf{b}, \mathbf{d}$ and f) $\times 85000$.

Table $4 P$-value for viable counts in different electric field experiments using repeated measures ANOVA with Bonferroni (step-down) Holm correction

\begin{tabular}{|c|c|c|c|c|c|c|c|}
\hline \multirow[b]{2}{*}{ Bacteria } & \multirow[b]{2}{*}{$\mathrm{EFS} /\left(\mathrm{V} \cdot \mathrm{m}^{-1}\right)$} & \multirow[b]{2}{*}{$\mathrm{EP} / \mathrm{mV}$} & \multicolumn{2}{|c|}{ FSB vs. NCB } & \multicolumn{2}{|r|}{ ESB vs. NCB } & \multirow[b]{2}{*}{ FSB vs. ESB } \\
\hline & & & ANOVA & ANOVA + Bonferroni-H & ANOVA & ANOVA + Bonferroni-H & \\
\hline \multirow[t]{5}{*}{ S. aureus } & 2 & 200 & 0.174 & 0.348 & 0.129 & 0.258 & 0.861 \\
\hline & 4 & 400 & $0.050 *$ & 0.15 & $0.006 *$ & $0.018^{*}$ & 0.292 \\
\hline & 6 & 600 & $0.028 *$ & 0.112 & $0.006 *$ & $0.024 *$ & 0.455 \\
\hline & 8 & 800 & $0.006^{*}$ & $0.03 *$ & $0.002^{*}$ & $0.01 *$ & 0.578 \\
\hline & 10 & 1000 & $0.0003^{*}$ & $0.0018 *$ & $0.001 *$ & $0.006^{*}$ & 0.675 \\
\hline E. coli & 10 & 1000 & 0.905 & 0.905 & 0.348 & 0.348 & 0.399 \\
\hline
\end{tabular}

ANOVA, analysis of variance; EFS, electric field strength; EP, electric potential; ESB: electrode-stimulated bacteria; FSB, field stimulated bacteria; NCB, negative control bacteria.

*Significant $(P \leqslant 0.05)$.

(Table 4). Univariate ANOVA revealed significant difference between the inhibition zones for $S$. aureus and E. coli $(P \leqslant 0.01)$ at EFS of 5,10 , 16 and $22 \mathrm{~V} \cdot \mathrm{m}^{-1}$ (Table 3).

\section{DISCUSSION}

This study investigated effects of LDC $(\mu \mathrm{A})$ electric fields and their electrochemical products on the growth of S. aureus and E. coli. The growth behaviour of some bacterial species can be influenced by low electric fields. The antibacterial effect of both alternating and direct electric current (AC and DC) and metal electrodes have been previously demonstrated in salt solutions ${ }^{21}$ and in synthetic urine. ${ }^{22}$ Rosenberg et al. ${ }^{23}$ noted the inhibition of E. coli by electrolysis products when $\mathrm{AC}$ has been conducted through platinum electrode. Pareilleux et al. ${ }^{21}$ studied the effects of $10-200 \mathrm{~mA}$ on E. coli viability and found the minimum current required to obtain bacterial death to be $25 \mathrm{~mA}$. Liu et al. ${ }^{24}$ showed the antibacterial effect of LDC (10$100 \mu \mathrm{A}$ ) on S. aureus in agar.
In the oral cavity, bacteria adhere to surfaces to form complex communities called biofilms. ${ }^{25-26}$ The growth of oral bacteria as a biofilm almost increases their resistance to antibacterial treatment compared with planktonic cultures that is grown in liquid media. ${ }^{27}$ However, It is possible to manipulate bacterial-surface electrostatic interactions by changing the surface polarity, the ionic strength conditions or by the application of an electric current. ${ }^{28-29}$ Electric manipulation of bacteria is possible since bacterial cells are generally negatively charged, which dictates their electrophoretic movement in DC fields ${ }^{30}$ and the enhancement of reversible adhesion. ${ }^{31}$ Poortinga et al. ${ }^{28}$ reported electrical detachment of biofilm formations from surgical implants. van der Borden et al. ${ }^{32}$ demonstrated that DCs of only $25-125 \mu \mathrm{A}$ stimulate detachment of staphylococcal strains from stainless steel. Moreover, del Pozo et al. ${ }^{33}$ published the marked decrease in the viability of $S$. aureus, $S$. epidermidis and $P$. aeruginosa biofilms after prolonged exposure to low-intensity electrical current of 20-2 $000 \mu \mathrm{A}^{33}$ 
Regarding metal ions released from galvanic reactions, it was confirmed that the electrochemical products from low current $(4.0 \mu \mathrm{A})$ stimulated gold electrodes in agar medium are bacteriostatic. ${ }^{34}$ Moreover, gold iontophoresis at $400 \mu \mathrm{A}$ was the most effective in eliminating or reducing bacterial growth. ${ }^{35}$ Generally, direct electric currents could inhibit biofilms on metal surfaces by elimination of planktonic cells before they adhere to the surface and initiate biofilm formation (attachment process) or by their interference with colonization and growth formation processes.

The intensity of evolving DC depends on different factors such as the electrode potential, polarization and distance between the electrodes, structure of the electrode surface, aeration, temperature, $\mathrm{pH}$ and composition of the electrolyte. In the present study, the difference in field produced by gold electrodes in TSB $\left(\leqslant 3 \mathrm{~V} \cdot \mathrm{m}^{-1}\right)$ and $0.9 \% \mathrm{NaCl}$ normal saline $\left(0.6 \mathrm{~V} \cdot \mathrm{m}^{-1}\right)$ was attributed to the difference in the chemical composition of media. Some electrodes may corrode and their corrosion products may interfere with the bactericidal effect of electrical current. ${ }^{22}$ In the present study, the gold alloy was chosen as electrode material to overcome this interference with current treatment.

In fluid media, the data of FSB revealed a significant decrease in the viability of $S$. aureus with a maximum reduction in their growth at $10 \mathrm{~V} \cdot \mathrm{m}^{-1}(P=0.0003)$, whereas no significant effect was observed on E. $\operatorname{coli}(P=0.905)$ in the same EFS, although over $24 \mathrm{~h}$, they did not reach its initial inocula levels. The effect of EFS is strongly dependent on the following parameters: bacterial structure, inoculum size, bacterial growth rate, growth medium composition and bacterial resistance. ${ }^{35-36}$ Thus, the difference in resistance between $E$. coli $(3.46 \mathrm{k} \Omega$ ) and $S$. aureus $(1.76 \mathrm{k} \Omega)$ in the same EFS of $10 \mathrm{~V} \cdot \mathrm{m}^{-1}$ may be one of reasons for the difference effect of EFS on tested bacteria. The second cause might be the induction of a heat shock response (stress protein synthesis) that protects cells against environmental stimuli including electric field. ${ }^{37-38}$

Earlier studies were in agreement with our findings; Davis et al. ${ }^{35-36}$ suggested that lower current of 325-375 $\mu \mathrm{A}$ delivered via gold wire could kill E. coli at low concentration of $1 \times 10^{3} \mathrm{CFU} \cdot \mathrm{mL}^{-1}$ within 2 days, but was variable in killing $E$. coli at high concentrated levels of $1 \times 10^{7} \mathrm{CFU} \cdot \mathrm{mL}^{-1}$. Thus, bacteria have a high survival rate in the denser inoculum than in the less-dense inoculum. ${ }^{36}$ As the reduction in bacterial growth was related directly to the intensity of current and inversely to bacterial concentration, ${ }^{35}$ high bacterial concentration at the beginning of the experiment $\left(1 \times 10^{6} \mathrm{CFU} \cdot \mathrm{mL}^{-1}\right)$ should be considered as a third cause. Furthermore, Obermeier et al. ${ }^{39}$ showed the reduction of $S$. aureus growth in fluid medium under the influence of DC electric field within $24 \mathrm{~h}$, and they noted that the DC electric field has strongest effects. No noteworthy corrosion, $\mathrm{pH}$ shifts and change in temperature were seen for gold electrodes in TSB at any level of DCV induction (data not shown).

In the present study, we proposed that the applied electric field increases the electric component of membrane potential $(\Delta \Psi$, negative inside) that hindered proton translocation to the outer side of the membrane, thus lowering both $\mathrm{pH}$ and adenosine triphosphate (ATP) synthesis. Additionally, due to the increased $\Delta \Psi$, the transport of electrons down the transport chain would also be prevented, and reduced compounds such as nicotinamide adenine dinucleotide $(\mathrm{NADH})$ or flavin adenine dinucleotide (FADH) would be accumulated. ${ }^{40}$ These compounds would lower both rates of main oxidative metabolic pathways and the nutrient consumption. ${ }^{41}$ This effect could be responsible for the shift-down-like response of tested bacteria to positive polarization. ${ }^{40}$

The data of ESB in this study revealed a significant inhibition of $S$. aureus growth $(P \leqslant 0.001)$, despite no current flow when compared to
E. $\operatorname{coli}(P=0.348)$. This inhibition is probably due to the formation of electrochemical reaction products particular to gold when used as sham electrodes in fluid media (oligodynamic reaction).

Once electrodes had immersed in TSB, the negatively charged bacteria interact with gold surfaces through attractive forces (van der Waals forces, acid-base interactions and electrostatic forces), ${ }^{42}$ and an open circuit potential of $(\leqslant 0.3 \pm 0.07) \mathrm{V}$ were produced. The adhesion of bacteria at this potential was irreversible and increased with the time of exposition. ${ }^{43}$ During the adhesion, bacteria are able to uptake gold ions for extracellular precipitation and transport. ${ }^{44}$ After transport process, gold ions combine readily with intracellular fluids to form a relatively insoluble compound that indicated as black particles in TEM. ${ }^{45-47}$ It has been demonstrated that Gram-positive bacterial cell wall is more efficient metal chelators because it contains a thick peptidoglycan layer responsible for bacterial adhesion to surfaces. ${ }^{44}$ One of the microbial responses to metals is the synthesis of intracellular metal-binding proteins. ${ }^{44}$

On agar medium (MHA), the influence of electric fields on the growth of $S$. aureus and E. coli was represented by the formation of inhibition zones only around the anode, which confirms the antibacterial effect of EFS at the anode. ${ }^{24}$ The zones of inhibition for S. aureus were larger than that for $E$. coli in all applied electric fields that clarify the ability of $E$. coli to withstand electric fields in agar medium too because of the reasons mentioned before. The gradual increase in zone's size may be due to the increase of electrochemical products that are directly proportional to the subjected DC electric field. ${ }^{24}$ Discoloration of agar at EFS of 16,22 and $27 \mathrm{~V} \cdot \mathrm{m}^{-1}$ suggested that physical changes related to electric field (discoloration at the anode and gas formation at the cathode) occur immediately in the area surrounding electrodes. ${ }^{48-49}$

Electric field-treated $S$. aureus revealed more ultrastructural changes than E. coli that exhibited little changes in cell morphology with no significant reduction in cell count. Changes like loss of membrane integrity with leakage of intracellular contents as a result of membrane damage were observed. ${ }^{24,50}$ Ultrastructural changes of tested bacteria are a result of their response to the environmental stresses generated by DC. ${ }^{51}$ The large surface area, double-membrane structure (inner- and outer-membrane) and motility provide E. coli the ability to protect themselves against LDC electric field in comparison to non-motile $S$. aureus cocci that has a single-membrane (innermembrane) with small spheroid surface area.

\section{CONCLUSION}

According to the present research, it was concluded that $S$. aureus is more sensitive to increasing electric field strength than E. coli and the influence of EFS treatment on $S$. aureus within fluid medium was significantly higher than in gel medium. The present data suggest that changes in oral ecosystem could be generated from small chronic influence of arising galvanic currents on bacterial growth. Therefore, it is recommended to prevent the occurrence of oral galvanism by avoidance of different metallic restorations in the oral cavity. Further studies are needed to determine if these galvanic currents can produce more resistant bacteria through studying the change in their genetic material.

1 Kucerová H, Dostálová T, Procházková J et al. Influence of galvanic phenomena on the occurrence of algic symptoms in the mouth. Gen Dent 2002; 50(1): 62-65.

2 Nogi N. Electric current around dental metals as a factor producing allergic metal ions in the oral cavity. Nippon Hifuka Gakkai Zasshi 1989; 99(12): 1243-1254. 
3 Toumelin-Chemla F, Lasfargues JJ. Unusual in vivo extensive corrosion of a low-silver amalgam restoration involving galvanic coupling: a case report. Quintessence Int 2003; 34(4): 287-294.

4 Certosimo AJ, O'Connor RP. Oral electricity. Gen Dent 1996; 44(4): 324-326.

5 Momoi Y, Asanuma A, Kohno A et al. A measurement of galvanic current and electrical potential in extracted human teeth. J Dent Res 1986; 65(12): 1441-1444.

6 Nilner K, Glantz PO, Ryge G et al. Oral galvanic action after treatment with extensive metallic restorations. Acta Odontol Scand 1982; 40(6): 381-388.

7 Ravnholt G, Holland RI. Corrosion current between fresh and old amalgam. Dent Mater 1988; 4(5): 251-254.

8 Nordenström BE. Biologically closed electric circuits (BCEC): clinical, experimental and theoretical evidence for an additional circulatory system. Stockholm: Nordic Medical Publications, 1983: 112-172.

9 Schriever W, Diamond LE. Electromotive forces and electric currents caused by metallic dental fillings. J Dent Res 1952; 31(2): 205-229.

10 Wartenberg M, Wirtz N, Grob A et al. Direct current electrical fields induce apoptosis in oral mucosa cancer cells by NADPH oxidase-derived reactive oxygen species. Bioelectromagnetics 2008; 29(1): 47-54.

11 Söremark R, Ingels $\mathrm{O}$, Plett $\mathrm{H}$ et al. Influence of some dental restorations on the concentrations of inorganic constituents of the saliva. Acta Odontol Scand 1962; 20: $215-224$.

12 Snyder DE. Incidence of painful oral electrogalvanism. Gen Dent 1987; 35(3): 198-199.

13 Sun ZL, Wataha JC, Hanks CT. Effects of metal ions on osteoblastlike cell metabolism and differentiation. J Biomed Mater Res 1997; 34(2): 29-37.

14 Wataha JC. Alloys for prosthodontic restorations. J Prosthet Dent 2002; 87(4): 351-363.

15 Takahashi N. Microbial ecosystem in the oral cavity: metabolic diversity in an ecological niche and its relationship with oral diseases. Int Congr Ser 2005; 1284: 103-112.

16 Bagg J, Sweeney MP, Harvey-Wood K et al. Possible role of Staphylococcus aureus in severe oral mucositis among elderly dehydrated patients. Microbiol Ecol Health Dis 1995; 8: 51-56.

17 Miyake $\mathrm{Y}$, Iwai M, Sugai M et al. Incidence and characterisation of Staphylococcus aureus from the tongues of children. J Dent Res 1991; 70(7): 1045-1047.

18 Smith AJ, Robertson D, Tang MK et al. Staphylococcal aureus infection in the oral cavity: a 3-year retrospective analysis of clinical laboratory data. Br Dent J 2003; 195(12): 701-703.

19 Ohara-Nemoto Y, Haraga H, Kimura S et al. Occurrence of staphylococci in the oral cavities of healthy adults and nasal-oral trafficking of the bacteria. J Med Microbiol 2008; 57(Pt 1): 95-99.

20 Lee PS, Lee KH. Escherichia coli: a model system that benefits from and contributes to the evolution of proteomics. Biotechnol Bioeng 2003; 84(7): 801-814.

21 Pareilleux A, Sicard N. Lethal effects of electric current on Escherichia coli. Appl Microbiol 1970; 19(3): 421-424.

22 Davis CP, Wagle N, Anderson MD et al. Bacterial and fungal killing by iontophoresis with long-lived electrodes. Antimicrob Agents Chemother 1991; 35(10): 2131-2134.

23 Rosenberg B, van Camp L, Krigas T. Inhibition of cell division in Escherichia coli by electrolysis products from a platinum electrode. Nature $1965 ; 205$ : 698-699.

24 Liu WK, Brown MR, Elliott TS. Mechanisms of the bactericidal activity of low amperage electric current (DC). J Antimicrob Chemother 1997; 39(6): 687-695.

25 Chen C. Periodontitis as a biofilm infection. J Calif Dent Assoc 2001; 92(5): 362369.

26 Costerton JW, Lewandowski Z, Caldwell DE et al. Microbial biofilms. Annu Rev Microbiol 1995; 49: 711-715.

27 Costerton JW, Stewart PS, Greenberg EP. Bacterial biofilms: a common cause of persistent infections. Science 1999; 284(5418): 1318-1322.

28 Poortinga AT, Smit J, van der Mei HC et al. Electric field induced desorption of bacteria from a conditioning film covered substratum. Biotechnol Bioeng 2001; 76: 395399 .

29 Ueshima M, Tanaka S, Nakamura S et al. Manipulation of bacterial adhesion and proliferation by surface charges of electrically polarized hydroxyapatite. J Biomed Mater Res 2002; 60(4): 578-584.
30 DeFlaun MF, Condee CW. Electrokinetic transport of bacteria. J Hazard Mater 1997; 55: 263-277.

31 Marshall KC, Stout R, Mitchell R. Mechanism of the initial events in the sorption of marine bacteria to surfaces. J Gen Microbiol 1971; 68: 337-348.

32 van der Borden AJ, van der Mei HC, Busscher HJ. Electric block current induced detachment from surgical stainless steel and decreased viability of Staphylococcus epidermidis. Biomaterials 2005; 26(33): 6731-6735.

33 del Pozo JL, Rouse MS, Mandrekar JN et al. Reduction of Staphylococcus and Pseudomonas biofilms by prolonged exposure to low-intensity electrical current. Antimicrob Agents Chemother 2009; 53(1): 41-45.

34 Spadaro JA, Berger TJ, Barranco SD et al. Antibacterial effects of silver electrodes with weak direct current. Antimicrob Agents Chemother 1974; 6(5): 637-642.

35 Davis CP, Arnett D, Warren MM. Lontophoretic killing of Escherichia coli in static fluid and in a model catheter system. J Clin Microbiol 1982; 15(5): 891-894.

36 Davis CP, Weinberg S, Anderson MD et al. Effects of microamperage, medium, and bacterial concentration on iontophoretic killing of bacteria in fluid. Antimicrob Agents Chemother 1989; 33(4): 442-447.

37 Mager WH, de Kruijff AJ. Stress-induced transcriptional activation. Microbiol Rev 1995; 59(3): 506-531.

38 Wójcik-Sikora A, Laubitz D, Pierzynowski S et al. Exposure of Escherichia coli to intestinal myoelectrical activity-related electric field induces resistance against subsequent UV $_{254 \mathrm{~nm}}$ (UVC) irradiation. Mutat Res 2001; 496(1/2): 97-104.

39 Obermeier A, Matl FD, Friess W et al. Growth Inhibition of Staphylococcus aureus induced by low-frequency electric and electromagnetic fields. Bioelectromagnetics 2009; 30(4): 270-279.

40 Busalmen JP, de Sánchez SR. Electrochemical polarization-induced changes in the growth of individual cells and biofilms of Pseudomonas fluorescens (ATCC 17552). Appl Environ Microbiol 2005; 71(10): 6235-6240.

41 White D. The Physiology and Biochemistry of Prokaryotes. 2nd ed. New York: Oxford University Press, 1995: 534-544.

42 Hermansson M. The DLVO theory in microbial adhesion. Colloids Surf B Biointerfaces 1999; 14: 105-119.

43 Busalmen JP, de Sánchez SR. Adhesion of Pseudomonas fluorescens (ATCC 17552) to nonpolarized and polarized thin films of gold. Appl Environ Microbiol 2001; 67(7): 3188-3194.

44 Gadd GM. Heavy metal accumulation by bacteria and other microorganisms. Cell Mol Life Sci 1990; 46: 834-840.

45 Seltzer S, Green DB, Weiner $\mathrm{N}$ et al. A scanning electron microscope examination of silver cones removed from endodontically treated teeth. Oral Surg Oral Med Oral Pathol 1972; 33(4): 589-605.

46 Reith F, Lengke MF, Falconer D et al. The geomicrobiology of gold. ISME J 2007; 1(7): 567-584.

47 Lengke M, Southam G. Bioaccumulation of gold by sulphate-reducing bacteria cultured in the presence of gold (I)-thiosulfate complex. Geochim Cosmochim Acta 2006; 70: 3646-3661.

48 Barranco SD, Spadaro JA, Berger TJ et al. In vitro effect of weak direct current on Staphylococcus aureus. Clin Orthop Relat Res 1974; (100): 250-255.

49 Merriman HL, Hegyi CA, Albright-Overton CR et al. A comparison of four electrical stimulation types on Staphylococcus aureus growth in vitro. J Rehabil Res Dev 2004; 41(2): 139-146.

50 Shimada K, Shimahara K. Leakage of cellular contents and morphological changes in resting Escherichia coli B cells exposed to an alternating changes. Agric Biol Chem 1985; 49: 3605-3607.

51 Sanin SL, Sanin FD, Bryers JD. Effect of starvation on the adhesive properties of xenobiotic degrading bacteria. Process Biochem 2003; 38: 909-914.

This work is licensed under a Creative Commons Attribution-NonCommercial-NoDerivative Works 3.0 Unported License. To view a copy of this license, visit http:// creativecommons.org/licenses/by-nc-nd/3.0 